Abstracta Iranica Abstranica

Revue bibliographique pour le domaine irano-aryen

Volume 27 | 2006

Comptes rendus des publications de 2004

\title{
"A Shahnama passage in an Achaemenid context ". Iranica Antiqua, vol. XXXIX, (2004), pp. 383-388.
}

\section{Rémy Boucharlat}

\section{(2) OpenEdition}

1 Journals

Édition électronique

URL : http://journals.openedition.org/abstractairanica/5721

DOI : 10.4000/abstractairanica. 5721

ISSN : 1961-960X

\section{Éditeur :}

CNRS (UMR 7528 Mondes iraniens et indiens), Éditions de l'IFRI

\section{Édition imprimée}

Date de publication : 15 mai 2006

ISSN : 0240-8910

\section{Référence électronique}

Rémy Boucharlat, « «A Shahnama passage in an Achaemenid context ». Iranica Antiqua, vol. XXXIX, (2004), pp. 383-388. », Abstracta Iranica [En ligne], Volume 27 | 2006, document 82, mis en ligne le 02 janvier 2007, consulté le 25 septembre 2020. URL : http://journals.openedition.org/abstractairanica/ 5721 ; DOI : https://doi.org/10.4000/abstractairanica.5721

Ce document a été généré automatiquement le 25 septembre 2020.

Tous droits réservés 


\title{
" A Shahnama passage in an
} Achaemenid context $»$. Iranica Antiqua, vol. XXXIX, (2004), pp. 383-388.

\author{
Rémy Boucharlat
}

1 L'A. poursuit une enquête qu'elle mène à travers plusieurs articles sur l'héritage achéménide dans la littérature médiévale iranienne, en partant de représentations de Persépolis ou, comme ici, d'inscriptions de Xerxès. Cette voie de recherche, explorée depuis plusieurs années, a remis à l'honneur la voie de transmission orale (les ménestrels), la plus probable pour expliquer le maintien de termes et d'images spécifiques.

\section{INDEX}

Thèmes : 3.2.1. Elam

\section{AUTEURS}

RÉMY BOUCHARLAT

IFRI-CNRS - Téhéran-Lyon 